\title{
Fracastor's Poem on Syphilis
}

Fracastor: Syphilis, or the French Disease; a Poem in Latin Hexameters

By Girolamo Fracastoro. With a Translation, Notes and Appendix by Heneage Wynne-Finch. Pp. vii $+253+4$ plates. (London : William Heinemann (Medical Books), Ltd., 1935.) 10s. 6d. net.

IN the introduction to this scholarly work, which admirably illustrates the close relation of medicine with literature, Mr. James Johnston Abraham, who is not only a well-known specialist in venereal diseases but also a writer of distinction, gives a short sketch of the life and times of Fracastor, and the origin and treatment of syphilis from the time of Fracastor until the present day.

In the preface to his translation, Mr. Heneage Wynne-Finch lays stress on the literary charm of the poem, which he declares has lately been neglected or obscured, though he admits that Fracastor occasionally indulges in tedious repetitions and redundancies. The poem, however, received the highest praise from contemporary writers such as Cardinal Bembo, the Venetian poet, to whom it is dedicated. Moreover, the popularity of the poem is shown by the fact that after its first appearance in 1530 at Verona, thirteen editions were published in the course of the sixteenth century.

Of Mr. Wynne-Finch's translation, which, unlike Natum Tate's verse rendering of 1686 is in prose, it may be said that he has admirably succeeded in his aim of retaining the grace and charm of the original, while keeping fidelity to the text.
The poem, which consists of three books, relates how a shepherd named Syphilus incurred the wrath of Apollo, who punished him by the infliction of a highly contagious and terrible new disease. A vivid description of the hideous sores and deformities of the unhappy victims is given in the first book, while the last two are mainly devoted to treatment, particularly by guiacum, on which Ulrich von Hutten had lavished such undeserved praise, and mercury.

The translation is followed by an essay on Fracastor and Virgil by Mr. Vernon Rendall, who illustrates by numerous examples Fracastor's use of Virgilian idiom and language as well as his resemblance to his master in his appreciation of the beautiful Italian country. Like Mr. Wynne-Finch, however, Mr. Rendall is not blind to Fracastor's shortcomings, and notes particularly the servile manner in which he takes incident and detail as well as words and phrases from the "Eneid". Mr. Rendall has also assisted Mr. Wynne-Finch in the preparation of copious notes on the poem, which include an abridged translation of the chapters on syphilis in Fracastor's other most important work, "De Contagione".

The book, which should appeal to all who are interested in the history of medicine or literature, is illustrated by portraits of Fracastor, facsimiles of pages from the first edition and first English translation and woodeuts of fifteenth century works on syphilis.

\section{Penetrating Ocean Depths}

\section{Half Mile Down}

By Dr. William Beebe. Pp. xix $+344+88$ plates. (London: John Lane, The Bodley Head, Ltd., 1935.) 18s. net.

$\mathrm{D}^{\mathrm{R}}$ . WILLIAM BEEBE is the born adventurer. To him the thrill of arriving where man has never arrived before is an unfailing stimulus to further exploits. When he turns from the tropical jungle and the desert to the ocean he does not rest until, inside a hollow steel ball, he has penetrated its depths to a distance of 3,028 feet beneath the surface. Even as he is making his hazardous journey down into the unknown the messages he sends along the telephone line to the surface reveal the driving spirit of the venture :
"We have just splashed below the surface."

"We are at our deepest helmet dive." $60 \mathrm{ft}$.

"The Lusitania is resting at this level." $285 \mathrm{ft}$.

"This is the greatest depth reached in a regulation suit by Navy divers."

"We are passing the deepest submarine record."

"The Egypt was found at this level by divers in rigid shells."

"A diver in an armoured suit descended this far into a Bavarian lake-the deepest point which a live human has ever reached."

"Only dead men have sunk below this." $\quad 600 \mathrm{ft}$.

"We are still alive and one-quarter of a mile down."

$1,426 \mathrm{ft}$ 